\title{
Updating the approaches to the classification of types and tools of the government regional policy
}

\author{
Inna V. Mitrofanova \\ Southern Federal Scientific Center \\ of the Russian Academy of Sciences, \\ Rostov-on-Don, Russia \\ Volgograd State University, \\ Institute of Economics and Finance, \\ Chair of the Economic \\ Theory, World and Regional Economics, \\ Volgograd, Russia \\ mitrofanova@ volsu.ru
}

\author{
Ekaterina V. Rodionova \\ Russian Presidential Academy of \\ National Economy and Public Administration \\ Volgograd Institute of Management, \\ Volgograd, Russia \\ rodionovaka1985@yandex.ru
}

\author{
Victoria V. Batmanova \\ Volgograd State University, \\ Institute of Economics and Finance, \\ Chair of the Economic Theory, \\ World and Regional Economics \\ batmanovavv@volsu.ru
}

\begin{abstract}
Terminological and conceptual ambiguity at the comprehension of the methods and tools of the government regional policy is one of the substantial reasons of the approval at different government levels of incorrect and unrealizable decisions concerning the creation of a mechanism of the support of regional social and economic regional complexes. The comparative analysis of various approaches allowed the authors classifying and clarifying the types of the government regional policy and it allowed also classifying the tools of the management of the regional development.
\end{abstract}

Keywords - regional policy, state, regulation, classification, instruments

\section{INTRODUCTION}

When using the term "government regional policy" the authors suggest meaning the development and the implementation at the federal and sub federal districts of the goals, tasks, priorities, methods and tools of the policy directed on the achievement of the competitive, stable, secure and sustainable development (inclusive development) of the subjects of the Federation (federal districts, regions, municipalities) in the current and actual (strategic) planning time frame [1].

The modernization of the government regional policy is thought to be connected with the strengthening of the differentiated approach to the regions of various types at the presence of a common goal i.e. the optimization of the territorial structure, growth of the standard and quality of life.
The policy of the region in its turn is expected to include all the complex of the methods and tools available for the regional authorities directed on the creation of the condition for an inclusive development of the territories. However the idea and the concept of the government regional policy require updating its types and the correction of the classification of the used instruments.

\section{MATERIALS AND METHODS}

The problems of the classification and the systematization of the tools of the government regional policy are studied in the papers of $\mathrm{O}$. Avtonomova, H. Armstrong, T. Bondarenko, O. Gritsai, G. Joffe, O. Kuznetsova, L. Limonova, A. Melnikova, I. Mitrofanova, I. Sukhareva, J. Taylor, A. Shvetsova and others and also they were analyzed in the reports of the World Bank, organization for Economic Cooperation and Development, OECD.

The range of the tasks set in this article predetermined by the necessity of the use of the corresponding methods of the study of the general and particular, analysis and synthesis, induction and deduction, generalization, analogy and extrapolation, economic modeling. In the paper in the system analysis the following methods were used: historical and logical, evolutionary, comparative and also the tools and the methods of the analytical hierarchy, expert assessments and so on. 


\section{RESULTS AND DISCUSSION}

Taking into consideration the postulates of the new economic geography and the theory of the endogenous growth the following types of the government regional policy are suggested: spatial and neutral (World Bank) and locally addressed (Organization for Economic Cooperation Development) [2, c. 115-116]. The main idea of the school of the World Bank consists in the following. The economic growth apriori is spatially uneven what inevitably leads to the regional differentiation. In the agglomerations the productivity is especially high as there the capital, infrastructure are accessible, the density of the business contacts is high. The government shouldn't intrude into the process of the distribution of people and resources. Meanwhile the achievement of the equal spatial growth is impossible due to the tools of the government regional policy. The state is expected to create the conditions for the concentration of the resources in the regions (growth points) within the spatial and neutral government regional policy.

In 2009 the OECD declared the new paradigm in the regional policy based on the acceleration of the growth in the regions leaders and in the regions outsiders in contrast to the policy dominating in the countries of the European Union when the depressive regions are paid back (in the form of subsidies and other types of governmental support) the expenses for the work in unfavorable conditions. The "new" government at all levels of the administration is in priority directed on the support of the integrated projects of the development for a fuller realization of the resource potential of the regions for the increase of their competitive position (locally addressed governmental regional policy) [2, pp. 6467; 3-5].

The evolution of the relations of the center and the region reflected on the ideas of the types of the government regional policy in the Russian regional science. O. Gritsai, G. Joffe and others suggest four types of the government regional policy. The first type is the stimulating government regional policy is directed on the acceleration of the economic development of regional economy due to an active support of new types of activity, creation of the necessary infrastructure and informational support. The goal of the second type of the compensating government regional policy is the leveling of the risks due to a more efficient distribution of the incomes, subsidizing and provision of privileges to the economic agents in the stagnating, crisis regions. The third type of the government regional policy can be entitled as the adaptive government regional policy and is focused on the adjustment of the life of people to special natural, social and economic conditions of a separate region. The fourth type is the counteracting government regional policy and is an indirect consequence of the incompetence of the subjects of the regional administration making wrong decisions not catalyzing but instead hindering the objective process of the regional development, "freezing" the "dead end" processes [6].

Judging from the goals and principles A. Shvetsov suggests three basic types of the government regional policy: 1) paternalist policy («top - bottom»), the general goal of which is the achievement of a more homogenous of the economic space of the country, the reduction of the differentiation at a degree in the levels of social and economic development of the subjects at the expense of priority government support to the region outsiders that makes necessary the solution of an important goal i.e. rational multicriterion decision taking into account the principle of the selectiveness in the conditions of the resource limits. That's why the mentioned above policy "freezes" the tendency of the centralization of the administration, growth of the dependence of the regions from the federal center; 2) competitive government regional policy is focused not on the direct contribution of the state to the development of a specific region or their group or on an active application of the mechanisms of the self development of each of them in general and the equal conditions of the competition. Its main attributive principle is its universal character when there is no excessive high, polarized social and economic differentiation of the regions and when the "center" sets only "rules of the game", conserves the independence of the subjects of the Russian Federation, leaves the freedom of choice in the questions of the regional development and full responsibility for the results of their realization «bottom-upwards»; 3) government regional policy of a mixed type is not homogenous has sub types differentiating in proportions and parameters which can be multiple [7, pp. 38-40].

A. Shvetsov choses two subtypes of the government regional policy of a mixed type: 1) general systematic government regional policy to which is mainly focused on the creation of the systemic wide prerequisites catalyzing the regional development by means of universal tools which do not have a special function, are not made for a specific region but which sculpture the economic, institutional and organizational sphere for the self-development of the subjects of the federation via the removal of the federal "barriers" (legal, organizational, administrative ones) hindering the process of the attraction of the investors to the efficient use of their investments [7, p. 42; 8, p. 99].

The goal of the selective government regional policy is the influence on the selected regions. It implies the transfer from the situational reaction of the state on the "alert signals" from separate regions to the systematization of the assessment of the situation in the regions, selection of regional situations, development and application of the measures of such government influence [7, p. 45; 8, p. 104-105]. It can be spoken about rather a selective and supportive character than about general systematic regulating and institutional aspect of such a policy under the conditions of the considerable centralization of resources and authorities.

There also exists an approach within which two types of the macro level of the government regional policy are suggested: the formalized one and the individualized one. In the frame of the government regional policy of a formalized type at the level of the government the criteria of the classification of the regions of the Russian Federation, ranking the regions into them and also the volumes of their financial support are drafted. In this case the personal decisions about the specific regions are not taken however each of them in case of the compliance with the established criteria can count 
on the participation in the federal target programs and consequently on the additional financing, new powers and so on. Partially such an approach exists even today, for instance at the distribution of the means of the Federal fund for regional support.

The individualized (subjective) type of the government regional policy is based on the construction of personal relations of the center and regions when there are no criteria and mechanisms of the government federal support. And if the formalized government regional policy is more predictable, has a more secure source of the financing the individualized government regional policy is more flexible as it takes into consideration the specificity and the needs of the regions.

The content of the government regional policy consists in the coordination of the measures of the general and of the selective policy. The first type is directed on the creation of the common prerequisites for a regional development. The measures taken are not selective and influence all the regions of the country by means of the creation of the organizational, legal and economic sphere of their individual activity. Within its scope the exact borders of the self development and common actions, powers and the responsibility of the authorities in all the questions of the territorial development, establishment of common rules, procedures and norms of the federal and regional division of the property, natural resources and finances are defined [9].

The selective government regional policy sets social goals and priorities that are mentioned in the conception (strategy) of the territorial (spatial) development of the country. It works selectively and in dependence on the object can be the polarizing one or the averaging one. The objects of the polarizing selective government regional policy are the regions with the highest development potential or so called "growth locomotives". It is directed on the encouragement of the development of the internal areas of the largest agglomerations and the implementation of the large scale programs on the basis of the "growth poles".

The averaging selective government regional policy is focused on the leveling of the economic development and investment potentials of the regions of the country. It can have both stimulating and constraining directions if its objects are overpopulated city areas (metropolises). In this case it is spoken about the constraining averaging selective government regional policy. If the problematic regions are depressive old industrial, agrarian, agrarian and industrial regions it can be spoken about the averaging selective government regional policy of the encouraging type which implies the encouragement of the investment inflow, financial support and so on) [9, pp. 110-111].

The authors agree that both the stimulating and the constraining selective government regional policy follow the principle of the social fairness when the distribution of the economic activity in the economic space creates for the population of all the regions equal opportunities for the achievement of the desirable standard and quality of life. The process of the creation of the selective government regional policy is connected with the search of a compromise between the goals of the polarizing and the averaging government regional policy which is determined by social priorities of the state in the middle term and short term periods, and also conditioned by the task of the considerable regional disproportions [9, p. 112].

O. Sukharev suggests two types of policy. The firs type is the standard (or classical) government regional policy focused on two problems: a) government support of the depressive regions; b) elimination of regional disproportions. The second type is the policy of a coordinated regional development policy of a triple direction which combines three types of policies: the "classical" regional policy, special internal economic policy lead by the administration of every specific region coming from the peculiarities of its development, and the policy of interregional relations and interactions [10; 11, pp. 10].

Summarizing all the mentioned approaches and taking into account the general idea the authors suggest the following classification of the government regional policy (Figure 1).

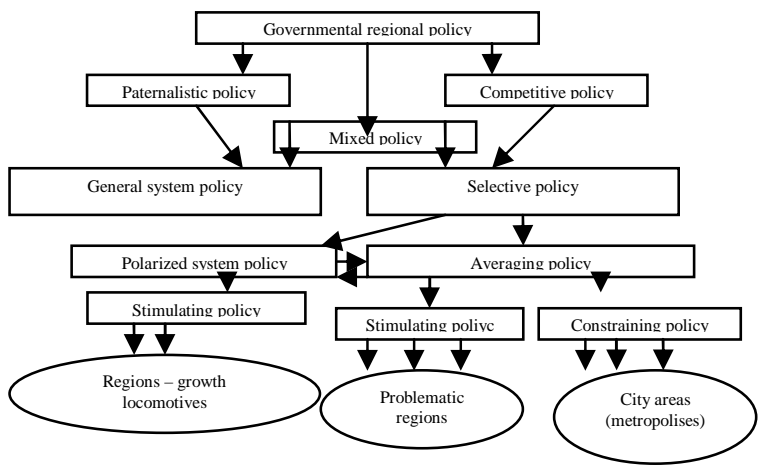

Figure 1. Typology of the governmental regions policy in Russia (according to goals).

The mechanism of the implementation of the government regional policy includes different methods with a number of specific tools. In the Russian science there often can be the substitution of these notions. When saying "tools" "we can mean huge systems of the economic relations like finance in general or like a state budget. Sometimes the tool is substituted by the method and in this case the planning or the economic encouragement are meant" [12].

The aggregate classification of the tools of the government regional policy into macro and micro tools was suggested by H. Armstrong and J. Taylor $[13 ; 14 ; 15$, p. 106]. The coordination and the harmonization of the use of micro tools (grants, subsidies, tax remissions, target loans and so on) influence the process of the inter industrial, interregional placement of the working force, capitals, macro tools connected with the changes in regional expenses and incomes in general. However the researchers mentioned above entitle them "methods" which is not correct and do not entitle them "tools". 
The suggested approach taken in its simplicity as authors think sometimes replaces methods by the tools. However it gives a certain order and understanding of the market tools of the regional policy. In the states of the federative structure the macro tools are mainly used by the government in the coordination with regional administration and the micro tools are used by the local or municipal administrations.

There exist the tools of the direct and indirect regulation. The direct regulation tools are subsidies for the support of some industries and regions (for the development of the infrastructure, support of the enterprises of the government and mixed property forms in the regions of the priority development); government investments (for the support of newly developed, stagnating regions or the most perspective types of the economic activities); price regulation in some goods, services (through regional tariffs), government orders, licenses, quotas for foreign trade and so on.

The current instruments of the indirect regulation are various types of crediting, tax mechanism as a universal regulator of the investment activity, production, trade and migration of the working force: tariffs (compensatory, antidumping, seasonal and so on). They are directed on the conservation of a common economic space of the country, assurance of the government interests in the foreign trade policy; accelerated amortization, creating additional stimuli for the increase of investments; activity of target and special extra budgetary funds and so on [15, pp. 100-101].

Partially we can agree with the classification suggested by O. Kuznetsova: all the tools of the government regional policy are divided into restraining ones which are mainly connected with the restraint of the growth of city agglomerations (for instance construction bans) and the promotional measures encouraging the development of the problematic regions [16].

Instruments of the sub federal regional policy are subdivided into a) tools implementing distributive functions; b) tools encouraging the implementation of some direction of regional policy regulating the actions of the enterprises, organizations and regions in the whole; c) tools having organizational and coordination functions [17, pp. 133].

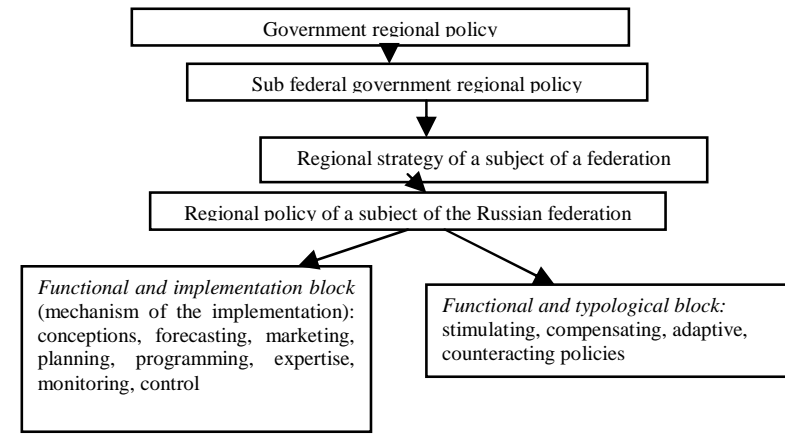

Figure 2. Structure and functional blocks of the regional policy [18, p. 11].
The diversity of methods and directions of the tools of the government regional policy can be harmonized through the presentation of its internal essence in the form of the functional and implementation; also functional and typological blocks (Figure 2).

The terminology and the substantive ambiguity in the understanding of methods and tools of the regulation of the regional development leads to the adaptation at various level of the voluntary, authoritarian and very often unrealizable, contradictive solutions.

The authors suggest to grade methods (blocks of methods) of the government regional policy from the point of view of the economic functions. They are strategizing (prognostics, planning, programming), intuition, organization, management (administration) investment, financing, regulation, informing, monitoring and so on (Table 1).

TABLE I. METHODS AND TOOLS OF THE GOVERNMENT REGIONAL POLICY IN RUSSIA

\begin{tabular}{|c|c|c|c|}
\hline \multirow[t]{2}{*}{ № } & \multicolumn{2}{|r|}{ Methods } & \multirow[b]{2}{*}{ Tools } \\
\hline & Block & $\begin{array}{c}\text { Functional } \\
\text { content }\end{array}$ & \\
\hline 1. & $\begin{array}{l}\text { Strate } \\
\text { gic }\end{array}$ & $\begin{array}{l}\text { activation, } \\
\text { forecasting, } \\
\text { strategizing, } \\
\text { programming, } \\
\text { planning, } \\
\text { modeling and so } \\
\text { on }\end{array}$ & 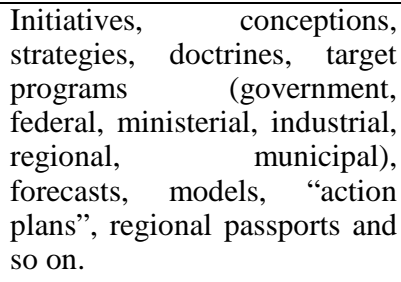 \\
\hline 2. & $\begin{array}{c}\text { Institut } \\
\text { ional } \\
\text { and } \\
\text { legal }\end{array}$ & $\begin{array}{l}\text { Establishment, } \\
\text { norm setting, } \\
\text { instruction, } \\
\text { regulation, } \\
\text { standardizing, } \\
\text { certification, } \\
\text { patenting } \\
\text { procedures, } \\
\text { licensing, } \\
\text { expertise, } \\
\text { copyright } \\
\text { protection, } \\
\text { accreditation, } \\
\text { evaluation and } \\
\text { so on }\end{array}$ & 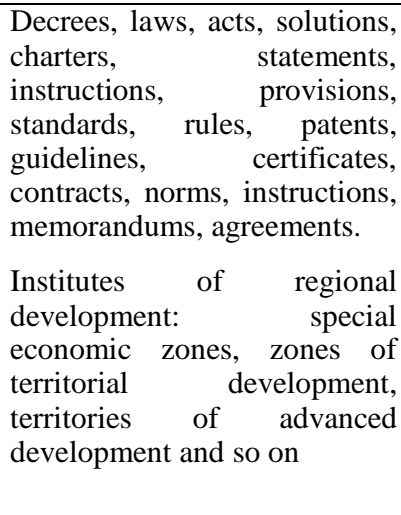 \\
\hline 3. & $\begin{array}{c}\text { Organi } \\
\text { zatinal } \\
\text { and } \\
\text { manag } \\
\text { erial }\end{array}$ & $\begin{array}{l}\text { Creation, } \\
\text { unification, } \\
\text { combining, } \\
\text { division, merger, } \\
\text { acquisition, } \\
\text { concentration, } \\
\text { cooperation, } \\
\text { collaboration, } \\
\text { specialization, } \\
\text { diversification, } \\
\text { differentiation, } \\
\text { net creation, } \\
\text { clustering, } \\
\text { outsourcing and } \\
\text { so on }\end{array}$ & $\begin{array}{l}\text { Personnel, time tables, } \\
\text { functions, coordination, } \\
\text { subordination, subdivisions, } \\
\text { groups, conferences, meetings, } \\
\text { instructions, accommodation } \\
\text { and so on. } \\
\text { Industrial parks, clusters, } \\
\text { technological parks and so on. }\end{array}$ \\
\hline
\end{tabular}




\begin{tabular}{|c|c|c|c|}
\hline \multirow[t]{2}{*}{ № } & \multicolumn{2}{|r|}{ Methods } & \multirow[b]{2}{*}{ Tools } \\
\hline & Block & $\begin{array}{c}\text { Functional } \\
\text { content }\end{array}$ & \\
\hline 4. & $\begin{array}{l}\text { Budge } \\
\text { ary } \\
\text { and } \\
\text { financi } \\
\text { al }\end{array}$ & $\begin{array}{l}\text { Investment } \\
\text { support, } \\
\text { subsidizing, } \\
\text { subventions, } \\
\text { transfers and so } \\
\text { on. }\end{array}$ & $\begin{array}{l}\text { Federal fund for regional } \\
\text { financial support (transfers to } \\
\text { the regions - recipients), } \\
\text { Federal fund for } \\
\text { compensations (subventions } \\
\text { for the implementation of the } \\
\text { functions), Federal fund for } \\
\text { co-financing of social } \\
\text { expenses (subsidies), Federal } \\
\text { fund for regional development } \\
\text { (subsidies for the averaging of } \\
\text { the regions with social and } \\
\text { engineering infrastructure), } \\
\text { Fund for the reforming of } \\
\text { regional and municipal } \\
\text { finances, Fund for the } \\
\text { contribution to the housing } \\
\text { sphere reforms, Investment } \\
\text { Fund of the Russian } \\
\text { Federation. }\end{array}$ \\
\hline 5. & $\begin{array}{l}\text { Invest } \\
\text { ment } \\
\text { and } \\
\text { financi } \\
\text { al }\end{array}$ & $\begin{array}{l}\text { Easy-term } \\
\text { lending, } \\
\text { insurance, } \\
\text { investments, } \\
\text { standards, } \\
\text { reinvestments, } \\
\text { project } \\
\text { financing, } \\
\text { leasing and so } \\
\text { on. }\end{array}$ & $\begin{array}{l}\text { Investment standard, grants, } \\
\text { bonuses, equity payments, } \\
\text { government orders, shares, } \\
\text { stocks, equity units, rewards, } \\
\text { interest rates, payment delays, } \\
\text { insurance rates, organizational } \\
\text { premiums, special non- } \\
\text { budgetary funds and so on. }\end{array}$ \\
\hline 6. & $\begin{array}{l}\text { Taxati } \\
\text { on and } \\
\text { admini } \\
\text { strative }\end{array}$ & $\begin{array}{l}\text { Tariff regulation, } \\
\text { tax and tariffs } \\
\text { incentives, tax } \\
\text { liberalization, } \\
\text { tax regression } \\
\text { and tax } \\
\text { progression, } \\
\text { structuring, } \\
\text { export licensing, } \\
\text { quotas, embargo, } \\
\text { customs } \\
\text { procedure } \\
\text { simplification } \\
\text { and so on. }\end{array}$ & $\begin{array}{l}\text { Taxes, tariffs, duties, tariff } \\
\text { quotas, payments, rates, base, } \\
\text { terms, incentives, amnesties, } \\
\text { fines, accelerated } \\
\text { amortization, penalties, tax } \\
\text { breaks, delays, preferences, } \\
\text { bans, export quotas, import } \\
\text { quota, license and so on. }\end{array}$ \\
\hline 7. & $\begin{array}{l}\text { Inform } \\
\text { ational }\end{array}$ & $\begin{array}{l}\text { Collection, } \\
\text { sorting, } \\
\text { processing, } \\
\text { classification, } \\
\text { storage, } \\
\text { accumulation, } \\
\text { transmission, } \\
\text { addressing } \\
\text { schemes, } \\
\text { channeling, } \\
\text { demonstration, } \\
\text { popularization, } \\
\text { advertising and } \\
\text { others }\end{array}$ & $\begin{array}{lr}\begin{array}{l}\text { Branding, } \\
\text { congresses, }\end{array} & \text { forums, sites, } \\
\text { contests, } & \text { exhibitions, } \\
\text { presentations, } & \text { workshops, } \\
\text { advertisements, } & \text { databases, } \\
\text { models, banners, instructions } \\
\text { and so on. }\end{array}$ \\
\hline
\end{tabular}

\begin{tabular}{|c|c|c|c|}
\hline \multirow[t]{2}{*}{ № } & \multicolumn{2}{|r|}{ Methods } & \multirow[b]{2}{*}{ Tools } \\
\hline & Block & $\begin{array}{c}\text { Functional } \\
\text { content }\end{array}$ & \\
\hline 8. & $\begin{array}{c}\text { Contro } \\
\text { l and } \\
\text { monito } \\
\text { ring }\end{array}$ & $\begin{array}{l}\text { Observations, } \\
\text { surveys (total, } \\
\text { sampling study), } \\
\text { calculation, } \\
\text { accounting, } \\
\text { controlling, } \\
\text { auditing, } \\
\text { monitoring, } \\
\text { expertise, } \\
\text { assessment, } \\
\text { correction }\end{array}$ & $\begin{array}{l}\text { Statements, } \\
\text { conclusions, invoices, } \\
\text { examination, acts, balance } \\
\text { sheets, assessments, prices, } \\
\text { indices (absolute, relative, } \\
\text { derived indices), integrated } \\
\text { indicators, points, places, } \\
\text { rankings and so on. }\end{array}$ \\
\hline
\end{tabular}

\section{CONCLUSION}

The current classification of the government regional policy includes three types of the government influence: paternalistic policy, competitive policy and mixed government regional policy. The mixed government regional policy is subdivided into two sub groups: general system (regulation and institutional) and selective system. The selective system includes two types: the polarizing policy and the averaging policy which in its turn is subdivided into two sub types: the stimulating one which catalyses the development of the problematic regions outsiders (depressive and crisis ones) and the restraining one which levels the growth of metropolises.

The decomposition of the methods of the government regional policy suggested by the authors into the functional blocks (strategic, institutional, organizational and managerial, budget and financial, investment and financial, taxation and administrative, informational, controlling and monitoring) and the suggestion for these blocks of the basic tools that allow partially eliminating the terminological and substantial ambiguity in the comprehension of the methods and tools of the regulation of the regional development and will allow improving the quality of the territorial management.

\section{Acknowledgment}

The article is prepared within the implementation of the governmental task of the Southern scientific Center of the Russian Academy of Sciences for year 2018, № of the state registration of the project is AAAA-A16-116012610047-9.

\section{References}

[1] Mitrofanova I.V., Batmanova V.V. Regional'naya ekonomika i politika [Regional economics and policy]. Volgograd. VolGU Publ., 2012, 378 p.

[2] Melnikova L.V. «Prostranstvenno-neitral'naya» i «lokal'no-adresnaya» regional'naya politika: problemy vybora ["Spatially neutral" and "locally adressed" regional policy: problem of choice:]. Region: ekonomika sotsiologiya [Region: economics and sociology], 2014, № 1, pp. 64-85.

[3] World Bank. World Development Report 2009: Reshaping Economic Geography. Washington, DC: World Bank, 2009, 383 p.

[4] OECD. How Regions Grow. P.: Organization for Economic Growth and Development, 2009, 197 p.

[5] OECD. OECD Regional Outlook 2011: Building Resilient Regions for Stronger Economies. OECD Publishing, 2011, 298 p. 
[6] Gritsai O.V., Joffe G.V., Treivish A. I. Tsentr i periferiya v regional'nom razvitii [Center and periphery in regional development]. Moscow: Nauka, 1991, $168 \mathrm{p}$

[7] Shvetsov A. N. Obshchesistemnaya i selektivnaya gosudarstvennaya regional'naya politika [General systematic and selective government regional policy]. Kontury global'nykh transformatsii: politika, ekonomika, pravo [Contours of global transformations: politics, economics, law], 2009, Vol. 2, № 1, pp. 38-50.

[8] Shvetsov A. N. Sovershenstvovanie regional'noi politiki: kontseptsii i praktika [Improvement of the regional policy: conceptions an practice]. Moscow: Krasand Publ., 2010, 320 p.

[9] Sidorenko O. V., Bondarenko T. N. Selektivnaya regional'naya politika gosudarstva [Selective regional policy of a state]. Vestnik Tomskogo gosudarstvennogo universiteta. Ekonomika [Bulletin of the Toms State University. Economics], 2014, № 3 (27), pp. 110-117.

[10] Sukharev O. S. Regional'naya ekonomicheskaya politika [Regional economic policy], Moscow: URSS Publ., 2014, 142 p.

[11] Sukharev O. S. Regional'naya ekonomicheskaya politika: strukturnyi podkhod i instrumenty [Regional economic policy: structural approach and tools]. Ekonomika regiona [Economy of a region]. 2015, № 2, pp. 9-22.

[12] Avtonomova O. A. Mekhanizm razvitiya nanoindustrii RF pod vozdeistviem globalizatsii: metody i instrumenty[Mechanism of the development of the nanoindustry in Russia under the impact of the globalization: methods and tools]. Vestnik VolGU. Seriya 3:
Ekonomika. Ekologiya [Bulletin of the Volgograd State University. Series 3. Economy. Ecology.], 2015, № 1(30), pp. 60-68.

[13] Armstrong H., Taylor J. Regional Economics and Policy (3rd edition). Oxford: Blackwell Google Books Preview, 2000, pp. 232-240.

[14] Rodionova E. V. Analiz organizatsionnykh izmenenii v sisteme regional'nogo upravleniya $\mathrm{v}$ Rossii [Analysis of the organizational changes in the system of the regional development in Russia]. Regional'naya ekonomika. Yug Rossii [Regional economy. South of Russia], 2014, № 4, pp. 38-43.

[15] Regional'naya ekonomika i prostranstvennoe razvitie v 2 tomakh. Tom 2. [Regional economics and spatial development. In 2 volumes. Vol. 2]. Edited by L.E. Limonov. $2^{\text {nd }}$ edition, corrected and updated. Moscow: Uright Publ., 2017. 367 p.

[16] Kuznetsova O. V. Regional'naya politika Rossii: diskussionnye voprosy sovremennogo etapa razvitiya [Regional policy of Russia: discussion questions of the current stage of development]. Regional'nye issledovaniya. [Regional studies], 2016, № 4, pp. 10-16.

[17] Marshalova A. S., Novoselov A.S. Regional'naya ekonomicheskaya politika sub"ekta Federatsii: problemy razrabotki i realizatsii [Regional economic policy of a subject of the federation: problems of the development and sociology], 2014, № 1 (81), pp. 124-144.

[18] Uskova T.V., Voroshilov N.V. Regional'naya politika territorial'nogo razvitiya: monografiya [Regional policy of the territorial development: monograph]. Vologda: ISERT RAN Pul., 2015, 156 p. 